\title{
ОСОБЛИВОСТІ ПРОВЕДЕННЯ СУДОВОӤ ПОЧЕРКОЗНАВЧОЇ ЕКСПЕРТИЗИ В МЕЖАХ ЦИВІЛЬНОГО ТА ГОСПОДАРСЬКОГО СУДОЧИНСТВА
}

\begin{abstract}
КРАВЧУК Олег Вікторович - доктор наук 3 державного управління, кандидат юридичних наук, доцент, заступник директора Хмельницького науководослідного експертно-криміналістичного центру МВС України, професор кафедри кримінального права та процесу, Хмельницький університет управління та права імені Леоніда Юзькова, місто Хмельницький

БАСЮК Максим Володимирович - завідувач сектору почеркознавчих досліджень відділу криміналістичних видів досліджень Хмельницького науководослідного експертно-криміналістичного центру МВС України

ГАЮР ІГОр Йосипович - кандидат юридичних наук, доцент кафедри права та правоохоронної діяльності Хмельницького інституту Міжрегіональної Академії управління персоналом, місто Хмельницький

В статье авторами исследованъ теоретические вопросъ назначения и проведения судебной почерковедческой экспертизъ в гражданском, хозяйственном и уголовном процессах. Акиентировано внимание на особенностях отобрания образиов почерка (подписи) для проведения сравнительного исследования. Освещень отдельнъие аспекть проведения оплать работь эксперта, а именно: оплата стоимости проведения почерковедческой экспертизы как услуги. Выполнено сравнение указанных процедур с аналогичнълми процедурами, проводимъгми в рамках уголовного процесса, установленъ и проанализированъ их расхождения. Авторами статьи предоставленъ собственнъе предложения по устранению проблемных моментов, возникающих на подготовительном этапе назначения экспертизы, на последуюших этапах ее проведения и оценки въгводов последней судом. Сбормированъг и приведенъ предложения по условиям правильного использования судом заключения эксперта. Сделанъ въгводъ и данъ рекомендаичи по согласованному применению норм действующего законодательства в практической деятельности эксперта и судьи. Обращено внимание на необходимости дальнейшего научного сотрудничества ученьх, специалистов в области материального и прощессуального права для улучшения инновачионной политики нашего государства и реализащии правовой ребормвг в Украине.

Ключевъие слова: эксперт, экспертиза, почерк, подпись, почерковедческая экспертиза, кодекс, образиъ, сравнительнъий материал, степень сложности исследования, оплата стоимости

Постановка проблеми

у наш час судово-почеркознавча експертиза дозволяє на основі використання спеціальних знань обізнаної особи в галузі судового почеркознавства вирішувати ідентифікаційні та неідентифікаційні завдання, які виникають у цивільному та господарському судочинстві.

Можливість вирішення експертом-почеркознавцем поставлених перед ним завдань визначається з урахуванням обсягу його знань щодо закономірностей формування почерку, даних про його індивідуальність та стійкість, класифікацію ідентифікаційних ознак почерку (^ітерного та цифрового) та підписів. Методики судово-почеркознавчого дослідження, які застосовуються експертом, засновані на 


\section{Цивільне, підприсмницьке, господарське та трудове право}

дослідженні якісних та кількісних характеристик ознак почерку, дозволяють вирішувати питання, що виникають у судовій практиці.

Повнота та достовірність висновків експерта значною мірою залежать від обсягу, характеру та безперечності походження порівняльних матеріалів, які надаються у розпорядження експерта судом.

Усе вищевикладене покладає величезну відповідальність на суд та експерта на шляху якісного збору доказової бази (шляхом проведення та дослідження експертного висновку) для справедливого, неупередженого та своєчасного розгляду та вирішення судом спорів 3 метою ефективного захисту порушених, невизнаних чи оспорюваних прав, свобод чи інтересів фізичних осіб, прав та інтересів юридичних осіб, інтересів держави. У цьому полягає актуальність досліджуваного питання.

\section{Аналіз останніх досліджень та публікацій}

Здійснений під час написання зазначеної наукової статті аналіз чинного законодавства, публікацій та наукових видань [1-8] показав, що вчені та практики неодноразово досліджували діяльність сторін судового провадження, експертів та суду щодо призначення та проведення почеркознавчої експертизи. Проте розгляд особливостей проведення судової почеркознавчої експертизи в межах цивільного та господарського судочинства вимагає свого детального дослідження та аналізу.

Мета статті - на підставі проведеного теоретичного аналізу та власного практичного досвіду експерта-правознавця визначити та проаналізувати особливості проведення судової почеркознавчої експертизи в межах цивільного та господарського судочинства, розглянути особливості відібрання зразків для проведення порівняльного дослідження, висвітлити окремі аспекти проведення оплати роботи експерта, а саме: оплати вартості проведення почеркознавчої експертизи як послуги, надати власні пропозиції щодо усунення проблемних моментів підготовчого етапу проведення почеркознавчої експертизи, пов’язані із збиранням матеріалів, та під час проведення експертного дослідження в установі, яка проводить експертизи.

\section{Виклад основного матеріалу}

Судова експертиза - це дослідження на основі спеціальних знань у галузі науки, техніки, мистецтва, ремесла тощо об'єктів, явищ і процесів з метою надання висновку 3 питань, що є або будуть предметом судового розгляду [1].

Що стосується почеркознавства, то воно є самостійною галуззю криміналістики, яка представляє собою систему знань про закономірності почерку, а також закономірності його розвитку та включає методи вирішення задач судової почеркознавчої експертизи.

Незважаючи на те, що розвиток комп'ютерної техніки в наш час зумовив перехід великої кількості документів у цифровий формат та з'явилися різноманітні системи електронного документообігу, почеркознавство як вид науково-експертної діяльності не втратило своєї актуальності, відповідно - експерти-почеркознавці не відчули на собі зниження навантаження, оскільки кількість спірних документів, підписаних або написаних певними особами, до цих пір залишається значною.

Інколи правові наслідки, які виникають після використання спірних документів, мають суспільнонебезпечний характер. У такому разі уповноважені органи (Національна поліція, Служба безпеки України, Державне бюро розслідувань, Національне антикорупційне бюро, органи доходів і зборів тощо), у відповідності до вимог статті 214 Кримінального процесуального кодексу України [2], розпочинають досудове розслідування із внесенням відомостей до Єдиного реєстру досудових розслідувань. Проте, у більшості випадків спори щодо використання та реалізації підроблених документів вирішуються сторонами у межах цивільного або господарського судочинства, оскільки склад кримінального правопорушення у діяннях сторін, як правило, відсутній, мають місце спірні питання щодо якості та 
своєчасності виконань умов укладеного договору.

За наслідками реалізації цих прав та виконання обов'язків сторонами договору виникають правовідносини, правову оцінку яким за наслідками вирішення спірних юридичних питань надає суд, залучаючи для цього спеціаліста у галузі почеркознавства як учасника судового процесу, наділяючи останнього процесуальним статусом «судовий експерт». Останній виступає експертом, т.б. - особою, яка володіє спеціальними знаннями, необхідними для з'ясування відповідних обставин у справі. Проведення почеркознавчих експертиз у цивільних і господарських провадженнях має свої особливості та дещо відрізняється від аналогічної дії у кримінальному процеci. Основними відмінностями є:

а) підготовка матеріалів і відібрання зразків для проведення експертизи,

б) оплата вартості проведення дослідження.

Порядок відібрання зразків детально описаний у Розділі I Методичних рекомендаціях щодо підготовки матеріалів для почеркознавчого дослідження [3]. Aле в кримінальному процесі орган досудового розслідування в особі слідчого, судді самостійно особисто отримують документи 3 вільними зразками почерку і підпису на підставі ухвали суду про тимчасовий доступ до речей і документів, маючи можливість ознайомитись із ними, оцінити їх важливість, якість, доцільність вилучення. У межах цивільного і господарського процесу вільні зразки почерку і підпису, зазвичай, надаються сторонами в судовому засіданні або направляються в суд підприємством, установою, організацією iз супровідним листом без обов'язкового пред'явлення їх власнику. Такий порядок надходження порівняльного матеріалу, на наш погляд, значно ускладнюе процес порівняльного дослідження у зв'язку із не підтвердженням достовірності порівняльного матеріалу.

Достовірність зразків - одна 3 трьох важливих вимог, які ставляться до порівняльного матеріалу. У разі надходження зразків без пред'явлення їх «особі-влас- нику», достовірність нічим не підтверджується. Зразки почерку і підпису в таких випадках інколи істотно різняться між собою, мають розбіжності з експериментальними зразками почерку і підпису тієї самої особи, що може свідчити про виконання зразків різними особами. У такому разі виникає необхідність у винесенні експертом клопотання про уточнення відомостей або надання додаткового достовірного порівняльного матеріалу.

На нашу думку, особливу увагу суд має приділяти перевірці достовірності (безперечності) походження вилучених вільних зразків почерку (підписів). 3 цією метою необхідно обов'язково пред'являти ці зразки тим особам, від імені яких вони виконані. Якщо в силу різних обставин (смерті чи тяжкої хвороби, служби у ЗСУ тощо) зробити це неможливо, зразки підписів (почерку) конкретної особи слід пред'являти особам, які можуть їх добре знати (родичам, товаришам по службі цієї особи, особливо касирам та бухгалтерам).

Найменування документів, які містять зразки почерку (підписів), які за отриманими даними виконані певними особами, повинні бути відображеними у протоко^і допиту (судового засідання) у вигляді відповідей позивача (відповідача, свідка). При цьому слід зазначати джерело отриманих відомостей.

Результати пред'явлення вільних зразків почерку (підписів) різним особам, що здійснюється для встановлення їх достовірності, повинні перевірятись судом. 3 цією метою можна зіставляти отримані від осіб, яким пред'являлися ті чи інші документи, дані з результатами огляду останніх судом, порівнювати вільні зразки почерку (підписів) конкретної особи з відповідними зразками, що містяться у протоколах допиту цієї особи, або зі зразками, які виконали цією особою за спеціальною вимогою суду (експериментальними зразками), аналізувати дані, отримані при пред'явленні тих самих документів різним особам. Особливо ретельно достовірність порівняльних матеріалів має перевірятися суддею, оскільки він не має можливості бути присутнім при вилученні зразків 


\section{Цивільне, підприсмницьке, господарське та трудове право}

у судово-процесуальних цілях, процедура виконання якої судом доручається правознавцям відповідної сфери діяльності.

При отриманні вільних зразків почерку (підписів) конкретних осіб успіх забезпечується дотриманням викладених вище вимог. Вважаємо за доцільне залучення почеркознавця при розгляді судом складних справ для отримання вільних зразків. Його допомога може полягати у наданні консультацій або у безпосередній участі у доборі та вилученні вільних зразків почерку (підписів).

Порядок витребування документів із вільними зразками почерку (підписів) судом визначається законодавцем у статтях 84 та 107 Цивільного процесуального кодексу України (далі ЦПК України) [4].

Так, експериментальні зразки почерку (підписів) - це рукописи (підписи), виконані певною особою за спеціальним завданням суду, обумовленим необхідністю підготовки матеріалів для судово-почеркознавчої експертизи.

Під час підготовки до відібрання експериментальних зразків необхідно на підставі відомостей, отриманих при огляді та 3'ясуванні обставин виконання документів, що підлягають експертному дослідженню, визначити, звичайні або спеціальні зразки повинні бути відібрані, умови їх відібрання (позу пишучого, звичність для нього знаряддя запису - виконання його кульковою, чорнильною ручками або олівцем та інш.), обсягом зразків, які відбираються (кількість сторінок рукописного тексту, цифрових записів, підписів), їх характер (підписи, рукописний текст, цифрові записи), які матеріали (бланки, папір 3 «лінівкою» або без неї, папір, розграфлений та розлінований від руки, шматки картону, дошки) та знаряддя, яким зазвичай здійснюються записи особою, яка надає зразки.

На нашу думку, суддя повинен особисто керувати відібранням експериментальних порівняльних матеріалів, оскільки це гарантує їх достовірність та високу якість. Як нами зазначалося попередньо, при розгляді судом складних справ до надання консультацій щодо методики відібрання експериментальних зразків або безпосе- редньої участі у цій дії може бути залучений експерт-почеркознавець.

Підставою для проведення судово-почеркознавчої експертизи є ухвала суду про призначення експертизи. Цей документ має складатися із суворим дотриманням правил статті 104 ЦПК України або статті 100 Господарського процесуального кодексу України (далі ГПК України) [5].

Статті 104 ЦПК України та 100 ГПК України не передбачають необхідність повідомлення в ухвалі про призначення експертизи обставин справи, за якою вона призначається. Проте статті 72 ЦПК України та 69 ГПК України надають експерту право знайомитися 3 тими матеріалами справи, які можуть мати значення для провадження експертизи (протоколи огляду, провадження, виїмки, допитів, судового засідання тощо). Оскільки в більшості випадків судово-почеркознавча експертиза проводиться не там, де розглядаються справи, тому всі матеріали конкретної справи, які мають значення для проведення експертизи, повинні фігурувати в ухвалі про її призначення.

В ухвалі про призначення судово-почеркознавчої експертизи необхідно формулювати завдання, яке ставиться перед експертом. Тому ми пропонуємо залежно від характеру завдання в питання, які ставляться на вирішення експертизи, включати такі дані: найменування документа, який подається на експертизу, чітко визначати початкові або заключні слова у тексті, які підлягають експертному дослідженню, дату складання цього документа, місцезнаходження досліджуваного об'єкта, прізвище, ім'я, по батькові передбачуваного виконавця спірного тексту (підпису), прізвище та ініціали особи, від імені якої виконано конкретний підпис, та зазначати чи не є ця особа, згідно з матеріалами справи, вигаданою, невстановленою або такою, що взагалі не вміє розписуватися.

Оцінка висновку експерта-почеркознавця судом повинна включати у себе визначення наукової обгрунтованості та достовірності його висновків, а також встановлення їх доказового значення для справи. 
На наш погляд, при визначенні наукової обгрунтованості висновків експерта необхідно з'ясовувати:

- чи проведено дослідження в межах цієї експертизи та компетенції експерта;

- чи достатній був (за характером та обсягом) досліджуваний почерковий матеріал, який міститься у документах - речових доказах та образах почерку (підписів), для зробленого експертом висновку;

- чи дотримано експертом методики дослідження, чи використано їм усі необхідні для успішного проведення експертизи методи.

Визначення достовірності висновків експерта має зводитися до зіставлення встановлених ним фактів з іншими доказами у справі.

Це досягається наступними процесуальними методами: допитом експерта; викликом експерта, який проводив експертизу до суду згідно з укладеним договором із стороною-замовником, викликом до суду для провадження експертизи з урахуванням відомостей, отриманих під час проведення судового слідства; проведенням додаткової чи повторної експертизи; провадженням інших процесуальних дій у суді (допит, одночасний допит, огляд документів тощо).

Якщо суд визнає висновки експерта науково обгрунтованими та достовірними, він повинен визначити значимість встановлених ним доказових фактів та в подальшому використовувати їх для встановлення обставин, які підлягають доказуванню. Отже, висновок експерта-почеркознавця, беззаперечно, може бути використаний судом як невід'ємної складової доказової бази під час прийняття кінцевого рішення у справі.

Строки, встановлені нормативними актами, для вирішення та надані відповіді на клопотання експерта, становлять щонайменше місяць, проте у визначених законодавцем випадках можуть бути продовжені. Усе це призводить до суттєвого збільшення обсягу часу, який витрачається учасниками процесу на встановлення об'єктивної істини у справі та винесення кінцевого рішення судом.
Щодо оплати проведення почеркознавчої експертизи, то в кримінальному процесі оплата проводиться після того як вирок суду вступає у законну силу. Підставою для оплати є наявність, власне, висновку експерта та довідки-рахунку вартості проведення такої експертизи. Разом із тим аналізом чинної системи розрахунків за надання послуг встановлено, що у цивільному та господарському процесах оплата проводиться безпосередньо перед початком проведення експертизи, оскільки професійна діяльність експерта для фізичних та юридичних осіб належить до категорії «платна послуга», яка затверджена постановою Кабінету міністрів України [6]. Вважаємо за необхідне дослідити та розкрити зазначене питання більш детально.

Так, як нами зазначено вище, проведення почеркознавчої експертизи в цивільному та господарському процесах є платною послугою для фізичних і юридичних осіб. Сторона, яка заявляє клопотання про призначення експертизи, фактично є замовником послуги, а установа (у нашому випадку: Науково-дослідний експертно-криміналістичний центр України) - є виконавцем. При надходженні ухвали про призначення експертизи до установи експерт-виконавець оцінює складність експертизи з метою вирішення вартості ії проведення.

Законодавцем України встановлено три види складності експертизи: проста, середня і складна, відповідно, залежно від складності варіюється і вартість оплати таких послуг.

Ми надаємо власну (авторську) пропозицію щодо визначення ступеню складності почеркознавчої експертизи.

Так, відповідно до вимог пункту 14 Розділу I Інструкції з організації проведення та оформлення експертних проваджень у підрозділах Експертної служби Міністерства внутрішніх справ України [7] судові експертизи та дослідження за складністю поділяються на категорії: прості, середні, складні (особливої складності).

Під час проведення простої експертизи досліджуються не більше десяти однорідних об’єктів, вирішуються не більше 


\section{Цивільне, підприсмницьке, господарське та трудове право}

трьох запитань та застосовуються не більше трьох загальнонаукових i/або спеціальних методів дослідження.

При проведенні експертизи середньої складності досліджуються від десяти до двадцяти однорідних i/aбо не більше десяти різноманітних об'єктів, вирішуються не більше п'яти запитань та застосовуються від трьох до п'яти загальнонаукових i/aбо спеціальних методів дослідження.

У ході проведення складної (особливої складності) експертизи досліджуються від двадцяти до ста (більше ста) однорідних i/або від десяти до двадцяти (більше двадцяти) різноманітних об'єктів, вирішуються п’ять і більше (шість і більше) запитань, застосовуються п'ять і більше загальнонаукових i/або спеціальних методів дослідження та два (більше двох) загальнонаукових i/або спеціальних методів дослідження.

Норми наказу Міністерства внутрішніх справ України заклали фундамент для подальшого визначення складності, а відповідно, і вартості проведення експертиз і досліджень. Якщо 3 кількістю об’єктів і кількістю поставлених запитань усе зрозуміло і їх підраховувати не складно, то із застосованою кількістю методів у декого із експертів можуть виникнути труднощі.

3 метою вирішення останніх розглянемо характеристики, які використовуються під час проведення почеркознавчих досліджень.

При проведенні почеркознавчої експертизи, у відповідності до рекомендації, які викладені у Розділі II Методики проведення судової почеркознавчої експертизи, застосовують загальні, загальнонаукові і спеціальні методи дослідження [8].

Загальні методи дослідження - це система логічних та інструментальних прийомів (операцій), спрямованих на пізнання явищ i процесів, який може бути використаний у переважній більшості наук. До загальнонаукових методів належать категорії і закони формальної логіки, аналіз і синтез, дедукція і індукція, моделювання, абстрагування, аналогія, узагальнення. Тобто це переважна більшість логічних процесів, які притаманні дієздатній особі.
До загальнонаукових методів відносяться методи: спостереження, вимірювання, опис, експеримент, порівняння, моделювання, реконструкція, системноструктурний аналіз, диференціальна діагностика.

До спеціальних методів відносяться такі методи: візуальний, мікроскопічний, фотографічний, графічний, ймовірно-статистичний.

Таким чином, маючи уявлення про методи, які використовуються в ході експертизи, їхню застосовану кількість, можна сміливо визначати категорію складності експертизи. Для прикладу наведемо декілька варіантів, які зустрічаються найчастіше в експертній практиці.

На дослідження надійшов один спірний документ, об'єктом дослідження $є$ один підпис, стосовно якого поставлене ідентифікаційне запитання: «Чи виконаний підпис в графі «Підпис» у договорі № 99 гр. С., чи іншою особою?». Експерт при дослідженні підпису застосовує спостереження (навмисне цілеспрямоване сприйняття), вимірювання (встановлення кількісних параметрів), описання (відображення умов і результатів дослідження), порівняння (зіставлення ознак різних об'єктів). Крім того, обов'язковою умовою дослідження підписів $є$ встановлення наявності або відсутності ознак технічної підробки підпису, для чого застосовується спеціальне обладнання із особливими умовами освітлення, що свідчить про використання спеціального методу - візуального (візуальне дослідження в особливих режимах освітлення, візуальне дослідження в невидимій зоні спектру). У результаті експерт робить висновок про наявність або відсутність тотожності. Таким чином, експерт використовує чотири загальнонаукових методи та два спеціальні. Отже, така експертиза відноситься до експертиз «середньої складності».

Інший варіант, коли на експертне дослідження надано один спірний документ, об'єктом дослідження є рукописний текст, стосовно якого поставлене діагностичне запитання: «Чи виконаний рукописний текст у заяві про звільнення під впливом 
збиваючих факторів?». Експерт при дослідженні почерку застосовує спостереження (навмисне цілеспрямоване сприйняття), вимірювання (встановлення кількісних параметрів), описання (відображення умов і результатів дослідження), робить висновок про наявність або відсутність ознак впливу збиваючих фаторів. Застосування спеціальних методів у цьому разі не обов'язкове. Таким чином, експертом застосовано три загальнонаукових методи. Отже, така експертиза відноситься до категорії «простих експертиз».

\section{Висновки}

Враховуючи специфіку призначення, проведення та оцінки доказового значення судової почеркознавчої експертизи, вважаємо за доцільне введення у практику систематичне проведення із працівниками суду, які відповідають за отримання зразків, занять відповідної спрямованості, що, у свою чергу, покращить діяльність експертних установ та суду в проведенні справедливого, неупередженого та своєчасного розгляду та вирішення справ з метою ефективного захисту порушених, невизнаних або оспорюваних прав, свобод ч інтересів фізичних осіб, прав та інтересів юридичних осіб, інтересів держави.

Надаючи оцінку категорії вартості проведення почеркознавчих експертиз, вважаємо за необхідне уніфікувати сучасний підхід до оцінки категорії складності експертиз, використовуючи для цього наведений у статті алгоритм. Зазначене утворюватиме єдиний об'єктивний підхід та сприятиме вирішенню проблематики в частині проведення та оцінки експертного дослідження.

\section{Література}

1. Закон України «Про судову експертизу» від 25.02.94 №4038-XII. Відомості Верховної Ради України (ВВР), 1994, № 28, ст.232) (редакція станом на 15.12.2020) [Електронний ресурс] : http://zakon.rada. gov.ua (дата звернення: 26.11.2021).

2. Кримінальний процесуальний кодекс України. Відомості Верховної Ради
України (ВВР), 2013, № 9-10, № 11-12, №13, ст.88. (редакція станом на 04.10.2021) [Електронний ресурс] : http://zakon.rada. gov.ua (дата звернення: 26.11.2021).

3. Наказ Міністерства юстиції «Про затвердження Інструкції про призначення та проведення судових експертиз та експертних досліджень та Науковометодичних рекомендацій з питань підготовки та призначення судових експертиз та експертних досліджень» від 08.10.1998 № 53/5 (редакція станом на 20.08.2021) [Електронний ресурс] : http://zakon.rada. gov.ua (дата звернення: 26.11.2021).

4. Цивільний процесуальний кодекс України. Відомості Верховної Ради України (ВВP), 2004, № 40-41, 42, ст.492. (редакція станом на 05.08.2021) [Електронний ресурс] : http://zakon.rada.gov.ua (дата звернення: 26.11.2021).

5. Господарський процесуальний кодекс України. Відомості Верховної Ради України (ВВР), 1992, № 6, ст.56. (редакція станом на 05.08.2021) [Електронний ресурс] : http://zakon.rada.gov.ua (дата звернення: 26.11.2021).

6. Постанова Кабінету Міністрів України «Про затвердження переліку платних послуг, які надаються підрозділами Міністерства внутрішніх справ, Національної поліції та Державної міграційної служби, і розміру плати за їх надання» від 04.06.2007 № 795 (редакція станом на 24.09.2021) [Електронний ресурс] : http://zakon.rada.gov.ua (дата звернення: 26.11.2021).

7. Наказ МВС «Про затвердження Інструкції 3 організації проведення та оформлення експертних проваджень у підрозділах Експертної служби Міністерства внутрішніх справ України» від 17.07.2017 № 591 (редакція станом на 17.07.2017) [Електронний ресурс] : http://zakon.rada. gov.ua (дата звернення: 26.11.2021).

8. Методика судової почеркознавчої експертизи. Загальна частина. / ДНДЕКЦ МВС України; Уклад. К.М. Ковальов, 3.С. Меленевська, Н.Г. Шпакович. - К., 2008, $123 \mathrm{c}$. 


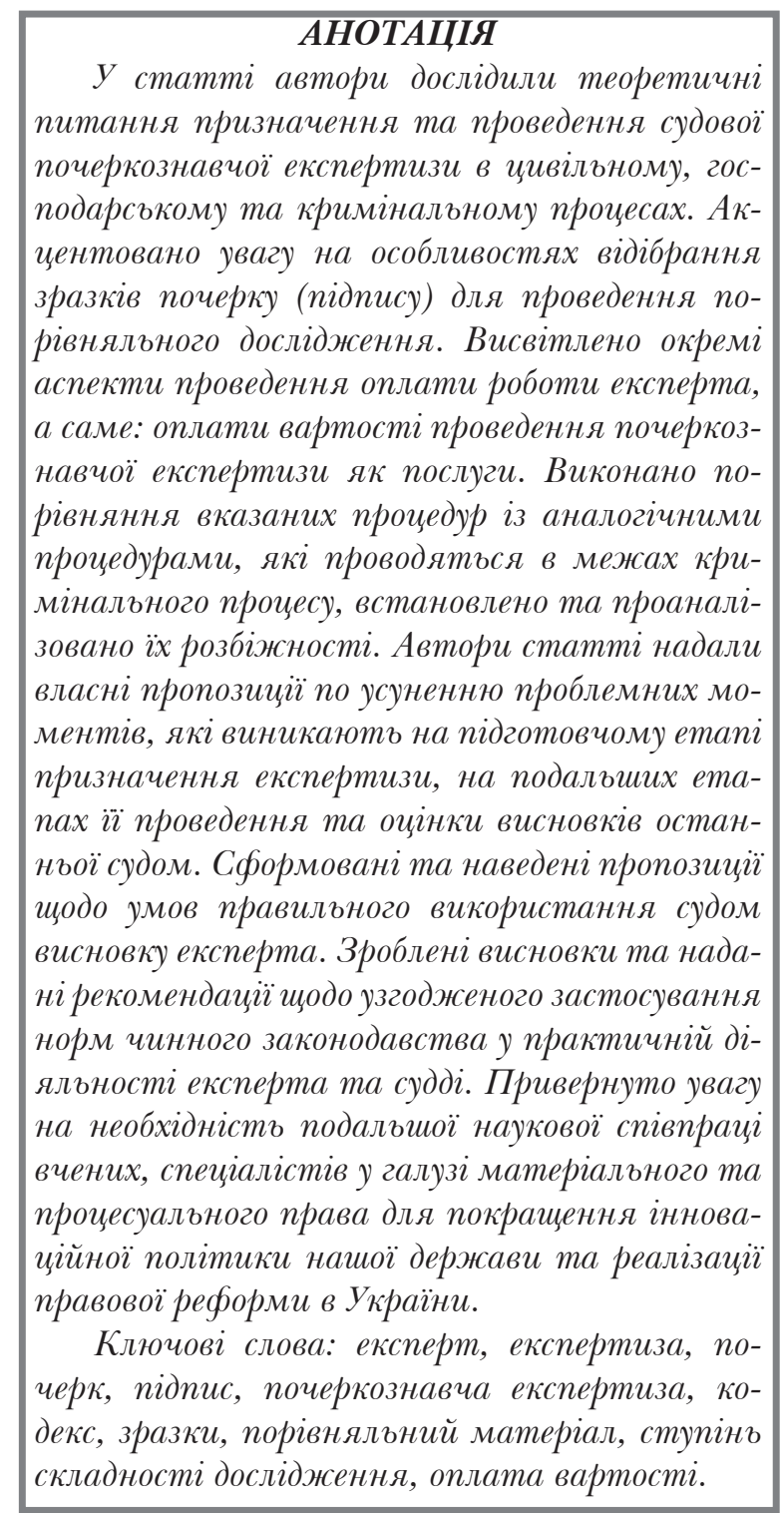

\section{O.V. Kravchuk, M.V. Basiuk, I.Y. Gayur FEATURES OF FORENSIC HANDWRITING EXAMINATION WITHIN GIVIL AND COMMERCIAL PROCEEDINGS}

In the article the authors investigate the theoretical issues of appointment and conduct of forensic handwriting examination in civil, commercial and criminal proceedings. Emphasis is placed on the peculiarities of taking handwriting samples (signatures) for a comparative study. Some aspects of payment for the work of an expert are covered, namely: payment for the cost of handwriting examination as a service. The comparison of the specified procedures with similar procedures which are carried out within the limits of criminal process is executed, their discrepancies are established and analyzed. The authors of the article provided their own proposals to eliminate the problematic issues that arise at the preparatory stage of the appointment of the examination, at subsequent stages of its conduct and evaluation of the conclusions of the latter by the court. Formed and presented proposals on the conditions of proper use by the court of the expert's opinion. Conclusions are made and recommendations are given regarding the coordinated application of the norms of the current legislation in the practical activity of the expert and the judge. Attention is drawn to the need for further scientific cooperation of scientists, specialists in the field of substantive and procedural law to improve the innovation policy of our state and the implementation of legal reform in Ukraine.

Keywords: expert, examination, handwriting, signature, handwriting examination, code, samples, comparative material, the degree of complexity of the study, payment. 